\title{
IMPLEMENTASI INSENTIF PAJAK UMKM DI ERA COVID-19 DI KECAMATAN GEDANGAN KABUPATEN SIDOARJO
}

\author{
${ }^{1}$ Alfi Huurin'lin, ${ }^{2}$ Septrian Jihan Aulia Fistabella, ${ }^{3}$ Adellia Nanda Savira, ${ }^{4}$ Kalvin Edo \\ Wahyudi
}

\author{
1,2,3,4 Program Studi Ilmu Administrasi Publik UPN "Veteran" Jawa Timur \\ kalvinedo.adne@upnjatim.ac.id \\ Surabaya, 60294, Indonesia
}

\begin{abstract}
It is known that the people's economy has experienced a significant decline due to the Covid - 19 Pandemic which has spread in various regions in Indonesia. From an economic point of view, we found that there was a decrease in income felt by UMKM actors, one of which was in the Gedangan Sub-District, Sidoarjo District which was caused by the Covid-19 pandemic. So that we are interested in examining how the efforts made by the Government through the Ministry of Finance regarding Final Income Tax Incentives to deal with the decline in income faced by UMKM's. This study aims to determine how the implementation of the Final PPh Tax Incentive policy for UMKM's during the current Covid-19 pandemic and to find out how the impact felt by UMKM's regarding the Final Income Tax incentives issued by the Indonesian Minister of Finance. The method we use in this research is descriptive qualitative with data collection techniques using interviews and observations. The results of this study indicate that the tax incentive policy can not be felt by UMKM actors in Gedangan District, this is due to the lack of socialization provided, resulting in their lack of knowledge about this policy and what conditions they must have to get tax incentives issued by the Ministry of Finance.
\end{abstract}

Keywords: Implementation: Policy; tax

\begin{abstract}
Abstrak
Diketahui bahwa ekonomi masyarakat mengalami penurunan cukup signifikan yang di akibatkan oleh Pandemi Covid -19 yang telah menyebar di berbagai wilayah di Indonesia. Dari sudut pandang ekonomi, kami menemukan terdapat penurunan pendapatan yang dirasakan oleh pelaku UMKM salah satunya di daerah Kecamatan Gedangan Kabupaten Sidoarjo yang diakibatkan oleh pandemi Covid-19. Sehingga kami tertarik untuk meneliti bagaimana upaya yang dilakukan oleh Pemerintah melalui Kementrian Keuangan terkait Insentif Pajak PPh Final untuk menangani penurunan pendapatan yang dihadapi UMKM. Penelitian ini bertujuan untuk mengetahui bagaimana implementasi dari kebijakan Insentif Pajak PPh Final untuk UMKM pada masa pandemi Covid-19 saat ini dan untuk mengetahui bagaimana dampak yang dirasakan UMKM tentang insentif pajak PPh Final yang dikeluarkan oleh Menteri Keuangan Indonesia. Metode yang kami gunakan dalam penelitian ini adalah Kualitatif Deskriptif dengan teknik pengumpulan data menggunakan wawancara dan observasi. Hasil penelitian ini menunjukkan bahwa kebijakan insentif pajak kurang bisa dirasakan oleh para pelaku UMKM Kecamatan Gedangan hal ini dikarenakan kurangnya sosialisasi yang diberikan sehingga mengakibatkan minimnya pengetahuan mereka tentang kebijakan ini dan syarat apa saja yang harus dimiliki untuk mendapatkan insentif pajak yang dikeluarkan oleh Kementerian Keuangan.
\end{abstract}

Keywords: Implementasi; Kebijakan; Pajak

Open Access at:http://ojs.uho.ac.id/index.php/PUBLICUHO/index

Journal Publicuho is licensed under a Creative Commons Attribution 4.0 International License. 


\section{Journal Publicuho}

ISSN2621-1351 (online), ISSN 2685-0729 (print)

Volume 4 Number 2 (May-July), (2021)pp. 520-535

Accredited SINTA SK.NOMOR 28/E/KPT/2019

Open Access at:http://ojs.uho.ac.id/index.php/PUBLICUHO/index

DOI: 10.35817/jpu.v4i2.18097

\section{PENDAHULUAN}

Pada tahun 2019 sampai saat ini tahun 2021, Covid-19 telah menjadi permasalahan yang serius di seluruh negara. Akibat adanya Covid-19, WHO (World Health Organization) menetapkan wabah ini menjadi pandemik. Sejak pandemi Covid-19 berlangsung potensi tingkat konsumsi dan daya beli masyarakat, penurunan kinerja perusahaan, ancaman pada sektor perbankan dan keuangan mengalami penurunan. Sehingga, Covid-19 akan menjadi ancaman yang serius bagi perekonomian nasional baik dari sektor pariwisata perdagangan dan investasi seperti sektor dominan perekonomian nasional. Hal ini, mengakibatkan peningkatan pengangguran. Namun, Keberadaan UMKM menjadi salah satu pilar ekonomi nasional yang telah terdampak pandemi covid-19 ini, mulai dari aspek total produksi, nilai perdagangan dan juga tenaga kerja yang harus kehilangan pekerjaannya. (Rozzaq \& Widiyarta, 2021)

Dalam perekonomian Indonesia, Usaha Mikro, Kecil, dan Menengah atau UMKM adalah kelompok usaha yang memiliki jumlah yang sangat besar. Keberadaan UMKM pada era Covid-19 saat ini memberikan dampak positif bagi perekonomian di Indonesia, keberadaan dari UMKM menjadi andalan pemerintah dalam mengurangi angka pengangguran di Indonesia yang masih tinggi karena belum tersediaanya lapangan kerja yang dapat menampung keberadaan tenaga kerja. Pemerintah harus mendukung perekonomi di Indonesia untuk menangani dampak yang ditimbulkan akibat Covid-19. Dalam penanganan untuk meningkatkan perekonomian pada UMKM, pemerintah mengeluarkan Kebijakan Insentif Pajak PPh Final untuk UMKM. Kebijakan tersebut dapat membantu UMKM di Indonesia untuk mendorong perekonomian. Pendapatan nasional suatu negara merupakan sebuah faktor penentu utama bagi kelangsungan proses pembangunan di negara tersebut, mengingat segala perencanaan pembangunan yang telah disusun akan sangat sulit terlaksana apabila tidak didukung oleh sumber daya keuangan yang memadai. Dan salah satu sumber pendapatan negara adalah Pajak.

Pajak menurut undang - undang yang kami gunakan, yaitu Undang-Undang Nomor 28 Tahun 2007 tentang perpajakan. Dimana dijelaskan bahwa pajak merupakan Kontribusi wajib yang diberikan rakyat kepada negara yang terutang oleh orang pribadi atau badan yang bersifat memaksa berdasarkan Undang-Undang, dengan tidak mendapatkan imbalan secara langsung dan digunakan untuk keperluan negara bagi sebesar-besarnya kemakmuran rakyat. Pada 27 April 2020 di tengah pandemi yang sedang melanda seluruh lapisan masyarakat, sebuah Peraturan Menteri Keuangan (PMK) telah diterbitkan. PMK Nomor 44/PMK.03/2020 yang berisikan tentang Insentif Pajak untuk Wajib Pajak Terdampak Pandemi Corona Virus Disease 2019 (Covid-19) baru saja diundangkan yang mana 
memunculkan satu jenis insentif pajak baru yakni PPh Final berdasarkan Peraturan Pemerintah Nomor 23 Tahun 2018 akan ditanggung oleh pemerintah (Insentif PPh Final UMKM DTP). Dengan adanya peraturan ini para pelakU UMKM dapat sedikit bernapas lega. Dari (Hel/Waw, 2020) salah satu daerah di Kabupaten Sidoarjo yakni Kecamatan Gedangan Kabupaten Sidoarjo merupakan salah satu daerah yang direncanakan sebagai sentra UKM oleh Bupati Bambang Haryo Soekartono. Menurutnya, 65 persen Pendapatan Asli Daerah (PAD) berasal dari sektor UMKM. Lagi pula, sektor UMKM juga menyerap 95 persen tenaga kerja, baik di Sidoarjo maupun secara nasional.

Berdasarkan uraian diatas, kami mengambil judul penelitian "Implementasi Insentif pajak UMKM di era Covid-19 diKecamatan gedangan Kabupaten Sidoarjo". Dengan dirumuskan pertanyaan penelitian yaitu bagaimana Implementasi Kebijakan Insentif Pajak PPh Final untuk UMKM di era Covid-19 di Kecamatan Gedangan Kabupaten Sidoarjo.

\section{Kebijakan Publik}

Menurut Dye (1987) kebijakan publik didefinisikan sebagai "Whatever governments chooses to do or not to do". Yang artinya adalah Kebijakan publik merupakan apa yang pemerintah pilih untuk melakukan sesuatu atau tidak melakukan sesuatu (Saraswaty, 2018). Aminullah dalam Muhammadi (2001:371-372) menyatakan bahwa kebijakan adalah suatu upaya atau tindakan yang dilakukan untuk mempengaruhi sistem pencapaian tujuan yang telah diinginkan. Selain itu, menurut David Easton, "Public Policy is the authoritative allocation of values for the whole society", yang artinya kebijakan publik adalah pengalokasian nilai-nilai yang telah disepakati secara sah kepada seluruh anggota masyarakat (Anggara, 2014). Dalam setiap kebijakan publik yang diterapkan, terdapat berbagai macam model-model dalam pengimplementasiannya.

\section{Implementasi Kebijakan}

Gordon dalam (Keban, 2004) mengatakan implementasi berhubungan dengan berbagai kegiatan yang telah ditujukan pada realisasi program. Yang artinya implementasi terdapat pada berbagai kegiatan maupun program yang tujuannya untuk menyelesaikan kegiatan atau program yang telah ditetapkan.

Demikian halnya menurut Jones (1991) dalam La Ode Muhammad Elwan, (2011: 18) menjelaskan bahwa Implementasi kebijakan mudah dimengerti secara teoritik dan konseptual, namun tidak senantiasa demikian dalam bentuknya yang kongkrit, karena pelaksanaannya secara nyata bukanlah sesuatu yang mudah (Supriadin et al., 2020) Ada beberapa model implementasi kebijakan publik, salah satu model implementasi kebijakan publik selain dari Edward III yakni yang telah diusulkan oleh Daniel Mazmanian dan Paul Sabatier. Mazmanian dan Sabatier mengungkapkan bahwa adanya peran penting dari analisis mengenai implementasi kebijaksanan negara ialah dengan mengidentifikasikan 


\section{Journal Publicuho}

ISSN2621-1351 (online), ISSN 2685-0729 (print)

Volume 4 Number 2 (May-July), (2021)pp. 520-535

Accredited SINTA SK.NOMOR 28/E/KPT/2019

Open Access at:http://ojs.uho.ac.id/index.php/PUBLICUHO/index DOI: 10.35817/jpu.v4i2.18097

semua variabel-variabel yang mendorong tercapainya tujuan-tujuan formal pada keseluruhan proses implementasi kebijakan(Wahab, 2001).

Dalam setiap model implementasi kebijakan publik mempunyai variabel, didalam Model Edward III sebagaimana yang dikutip oleh Aminullah (2015) ini mengisyaratkan bahwa keberhasilan dari implementasi ditentukan oleh variabel komunikasi, sumberdaya, disposisi, dan struktur birokrasi (Aminullah \& Setyasih, 2021). Dalam (Kadim, 2015) dijelaskan 4 variabel tersebut yakni :

a. Komunikasi, menunjuk pada setiap kebijakan maupun program yang akan dapat dilaksanakan dengan baik apabila terjadi komunikasi efektif antara pelaksana kebijakan/ program dengan para kelompok sasaran (target groups). Sasaran dan tujuan yang dimiliki program kebijakan adalah agar disosialisasikan secara baik dan benar sehingga berhasil menghindari adanya penyimpangan pemahaman atas kebijakan dan program, ini menjadi persoalan yang penting karena semakin tinggi wawasan atau pemahaman kelompok sasaran atas program atau kebijakan yang telah terbentuk, maka dengan memilki wawasan kelompok yang tinggi dan soasialisasi yang dilakukan secara baik, akan menghasilnya hasil yang memuaskan. Yaitu akan berkurangnya tingkat penolakan dan kekeliruan dalam mengaplikasikan program dan kebijakan dalam ranah yang sesungguhnya.

b. Sumber daya, menunjuk setiap kebijakan atau program yang harus mendapat dukungan oleh sumber daya yang cukup layak atau bahkan layak, baik dari sumber daya manusia maupun sumber daya finansial. Sumber daya manusia adalah kualitas maupun kuantitas yang cukup baik dimiliki oleh pelaku implementasi kebijakan (implementor) yang dapat melingkupi maupun mencakup seluruh kelompok yang menjadi target sedangkan sumber daya finansial adalah setiap program, maupun kebijakan yang memiliki cukup modal invenstasi.

c. Disposisi, menunjuk pada karakteristik yang harus dimiliki oleh para implementor kebijakan (pelaku implementasi). Karakter yang harus dimiliki oleh implementor kebijakan adalah dengan memiliki sifat jujur, komitmen dan demokratis. Karakter tersebut diharuskan menyatu dalam diri para implementor hal ini dikarenakan apabila para pelaku implementasi tidak memiliki sifat-sifat tersebut, bagaimana mungkin masyarakat yang akan menjadi target kebijakan bisa mempercayai kebijakan yang telah dikeluarkan tersebut.

D. Struktur birokrasi, menunjuk bahwa keberadaan struktur birokrasi menjadi salah satu poin yang penting tidak dapat diabaikan dalam implementasi kebijakan. Aspek dari struktur birokrasi ini terdapat dua hal penting, yang pertama adalah mekanisme, dan kedua adalah struktur organisasi pelaksana sendiri. Mekanisme implementasi kebijakan atau program biasanya sudah ditetapkan yang sudah dicantumkan dalam dalam Guideline kebijakan/program, hal itu merupakan Standar Operating Procedur (SOP) yang sudah 
dijelaskan. Dalam pengimplementasian kebijakan tersebut, akan selalu mengambil dan memilih satu topik dari kebijakan tersebut, maka kami mengambil topik pembahasan yang mengerucut kepada kebijakan Insentif Pajak.

\section{Insentif Pajak}

Merupakan pajak yang dipungut dari penghasilan atas usaha-usaha yang telah diciptakan dan didaftarkan oleh Wajib Pajak dengan peredaran bruto tertentu yang bersifat final, dan dimaksudkan untuk memberikan kemudahan bagi para pelaku wajib pajak yang menerima atau memperoleh pendapatan/penghasilan dari usaha tersebut dengan peredaran bruto tertentu dapat melakukan penghitungan, penyetoran, dan pelaporan pajak penghasilan yang terutang (Resmi, 2019). Berdasarkan (Aningtiyas, 2020) Pemerintah melalui Otoritas Jasa Keuangan (OJK) sedang memperkirakan dan menghitung kebutuhan modal kerja darurat yang nantinya akan diberikan kepada para pelakU UMKM yang telah terdampak pandemi Covid-19, pemerintah juga berupaya memberikan pembebasan membayar pajak kepada para pelaku UMKM selama enam bulan. Pembebasan membayar pajak tersebut merupakan hasil dari Peraturan yang dikeluarkan oleh Menteri Keuangan yaitu PMK-44/PMK.03/2020 yang berisikan tentang Insentif Pajak yang diberikan kepada Wajib Pajak yang Terdampak Pandemi Covid-19. Adapun bentuk dari insentif pajak untuk pelaku UMKM adalah PPh Final UMKM yang telah diitanggung Pemerintah (DTP), bagi wajib pajak yang memiliki peredaran bruto kurang dari 4,8 miliar dalam setahun yang sebelumnya telah menggunakan tarif pajak sebesar $0,5 \%$ berdasarkan Peraturan Pemerintah nomor 23 Tahun 2018. Informasi ini dapat dilihat di akun media sosial @DitjenPajakRI maupun Kantor Pelayanan Pajak yang telah terdaftar. Setelah PMK-44/PMK.03/2020 sudah dicabut, dilakukan pembaruan secara berkala tentang PMK terkait insentif pajak ini hingga munculnya PMK-09/PMK.03/2021 Tentang INSENTIF PAJAK UNTUK WAJIB PAJAK TERDAMPAK PANDEMI CORONA VIRUS DISEASE 2019 (Covid-19) dan ada perubahan didalam peraturan tersebut salah satunya pelaku UMKM mendapat fasilitas pajak penghasilan final tarif $0,5 \%$ (PP 23/2018) yang ditanggung pemerintah hingga 30 Juni 2021 (Dewantari, 2021).

Dalam penelitian lain, didalam jurnal yang berjudul "Dampak COVID - 19 Terhadap Perlambatan Ekonomi Sektor UMKM" dengan penulis (Pratiwi, 2020), dalam penelitian yang ditulis memiliki persamaan dengan penelitian kami yakni "dampak yang dirasakan oleh UMKM yang diakibatkan Pandemi Covid-19". Namun, juga memiliki perbedaan yakni dalam "penelitian tersebut membahas tentang dampak covid-19 terhadap perlambatan ekonomi Sektor UMKM serta upaya pemerintah memperkuat UMKM sedangkan dalam penelitian ini kami membahas bagaimana implementasi Kebijakan Insentif Pajak PPH Final untuk UMKM di Era Covid-19 di Kecamatan Gedangan Kabupaten Sidoarjo". Pada penelitian yang lain dengan judul "Studi Kritis Pengenaan Pajak Penghasilan Final Bagi Usaha Mikro Kecil Menengah" dengan penulis (Maharatih, 2019) yang dalam penelitian yang ditulisnya 


\section{Journal Publicuho}

ISSN2621-1351 (online), ISSN 2685-0729 (print)

Volume 4 Number 2 (May-July), (2021)pp. 520-535

Accredited SINTA SK.NOMOR 28/E/KPT/2019

Open Access at:http://ojs.uho.ac.id/index.php/PUBLICUHO/index

DOI: 10.35817/jpu.v4i2.18097

memiliki persamaan yakni membahas tentang "PPh Final untuk UMKM" namun perbedaan dalam penelitian kami adalah "kami menganalisis bagaimana implementasi kebijakan insentif pajak PPh Final untuk UMKM di masa pandemi saat ini."

Selanjutnya, pada penelitian yang berjudul "Implementasi Kebijakan Pemberian Bantuan Keuangan Kepada Pemerintah Desa Di Kabupaten Bandung" oleh (Mulyadi, 2019), penelitian tersebut memiliki persamaan dengan penelitian kami yakni "membahas implementasi kebijakan dari pemerintah" namun yang menjadi pembeda adalah "dalam penelitian tersebut membahas Kebijakan Pemberian Bantuan Keuangan sedangkan dalam penelitian kami membahas kebijakan insentif pajak PPh Final."

Penelitian ini bertujuan untuk mengetahui bagaimana implementasi dari kebijakan Insentif Pajak terutama PPh Final untuk UMKM pada masa pandemi Covid-19 saat ini dan untuk mengetahui bagaimana dampak yang dirasakan UMKM tentang insentif pajak PPh Final yang dikeluarkan oleh Menteri Keuangan Indonesia serta kami mencoba untuk melihat tingkat keberhasilan implementasi insentif pajak PPh Final untuk UMKM yang dilakukan pada era Covid-19 yang mana diketahui bahwa Implementasi kebijakan memiliki beberapa variabel, dimana masing-masing variabel implementasi kebijakan publik memiliki perbedaan.

\section{METODOLOGI}

Dalam penelitian ini, metode penelitian yang kami gunakan adalah adalah penelitian kualitatif. Menurut (Moleong, 2005), penelitian kualitatif yaitu penelitian yang memiliki tujuan untuk memahami fenomena terhadap subjek penelitian tentang apa yang dialami oleh subjek tersebut misalnya perilaku, tanggapan, motivasi, aktivitas, dan lainnya secara holistic, dan dengan mendeskripsikan dalam bentuk bahasa dan kata-kata, pada suatu situasi khusus yang alamiah dan dengan memanfaatkan berbagai macam metode alamiah. Berdasarkan pengertian yang diberikan, penelitian kualitatif dipandang cocok untuk dijadikan metode dalam penelitian kami, hal ini dikarenakan untuk memahami fenomena yang terjadi yakni implementasi kebijakan insentif pajak dalam bentuk persepsi dari subjek penelitian yang diolah dalam bentuk metode alamiah.

Penelitian ini dilakukan pada Bulan April 2020 dengan berlokasi di Kecamatan Gedangan Kabupaten Sidoarjo Provinsi Jawa Timur, Dinas Koperasi dan UKM (Usaha kecil dan menengah) Provinsi Jawa Timur serta Dinas Koperasi dan Usaha Mikro Kabupaten Sidoarjo. Penelitian ini menggunakan berbagai sumber data yang akan diolah, beberapa diantaranya akan dikumpulkan melalui website resmi DJP (Direktorat Jenderal Pajak), mengambil data dari wawancara dengan Dinas Koperasi dan UKM Provinsi Jawa Timur, Dinas Koperasi dan Usaha Mikro Kabupaten Sidoarjo, disisi lain kami mengumpulkan data melalui studi kepustakaan terhadap buku-buku dan jurnal-jurnal yang menjadi gambaran kami dalam mengerjakan penelitian ini. 
Teknik analisis yang akan kami lakukan adalah yang pertama melakukan pengumpulan data dengan teknik triangulasi data menurut Miles dan Huberman (1984) melalui wawancara yakni tentang insentif pajak, kedua reduksi data dengan meringkas hasil penelitian. Ketiga, penyajian data dalam bentuk deskripsi . keempat adalah menarik kesimpulan dan verifikasi.

\section{HASIL DAN PEMBAHASAN}

Pada saat ini, pemandangan ekonomi telah berubah secara dramatis. penyempitan kegiatan ekonomi dan pandemi global Corona Virus atau sering disebut COVID-19 yang terjadi saat ini membuat ekonomi tidak dapat bergerak secara lelvasa, dengan pandangan bahwa Covid-19 telah menggiring ekonomi dunia kepada kemunduran yang berkepanjangan dan semakin lebih parah yang akan terjadi kedepannya (Muhyiddin \& Wardhana, 2020). COVID-19 telah diklasifikasikan sebagai virus yang diagnosisnya diawali dengan gejala umum berupa demam, batuk dan flu hingga kesulitan bernapas dan penyebarannya telah memberikan dampak infeksi pada saluran pernapasan dari ringan hingga sedang, (Padyanoor, 2020). Dalam (Yuliana, 2020) Virus Corona atau severe acute respiratory syndrome coronavirus 2 (SARS-CoV-2) adalah virus yang menyerang sistem pernapasan pada manusia. Virus Corona bisa menyebabkan gangguan ringan pada sistem pernapasan, infeksi paru-paru yang berat, hingga kematian. Penyakit yang disebabkan infeksi virus ini disebut COVID-19. Severe acute respiratory syndrome coronavirus 2 (SARSCoV-2) yang lebih dikenal dengan nama virus Corona adalah jenis baru dari coronavirus yang menular ke manusia. Virus ini bisa menyerang siapa saja, seperti lansia (golongan usia lanjut), orang dewasa, anak-anak, dan bayi, termasuk ibu hamil dan ibu menyusui. Saat ini, akibat COVID-19, seluruh dunia tengah menghadapi krisis kesehatan global dan sosial ekonomi yang belum pernah terjadi sebelumnya.

Di seluruh dunia saat ini sedang terjadi sebuah pandemi yang mempunyai dampak cukup besar bagi semua lapisan dan sektor kehidupan manusia. World Health Organization (WHO) telah menetapkan Coronavirus Disease 2019 atau COVID-19 sebagai sebuah ancaman pandemic bagi kehidupan ini. Pengertian pandemi menurut Kamus Besar Bahasa Indonesia (KBBI) merupakan wabah yang berjangkit serempak di mana-mana atau meliputi wilayah yang luas. Kasus ini muncul bermula terjadi di Wuhan, Tiongkok dan mulai menyebar ke hampir seluruh dunia. Penyebaran COVID-19 ini sangat cepat dan tidak ada yang mempu memprediksi kapan berakhirnya pandemi COVID-19 ini. Kasus Covid-19 yang merupakan pandemi global jelas menimbulkan kekhawatiran dari beragam kalangan, khususnya masyarakat. Kekhawatiran yang dirasakan oleh masyarakat semakin sangat terasa dengan melihat terjadinya lonjakan dari kasus ini dengan cukup cepat, dan melihat kurangnya kesiapan beberapa elemen dari segala bidang yang cukup vital guna "memerangi" virus corona. Tingkat persebaran virus tersebut yang bisa dikatakan tinggi 


\section{Journal Publicuho}

ISSN2621-1351 (online), ISSN 2685-0729 (print)

Volume 4 Number 2 (May-July), (2021)pp. 520-535

Accredited SINTA SK.NOMOR 28/E/KPT/2019

Open Access at:http://ojs.uho.ac.id/index.php/PUBLICUHO/index

DOI: 10.35817/jpu.v4i2.18097

sehingga begitu cukup mengharuskan pemerintah untuk segera mengambil langkah strategis untuk menyesuaikan dengan bagaimana keadaan secara langsung masyarakat. Pemerintah dengan menetapkan kebijakan-kebijakan antisipatif untuk mengatasi dampak dari Covid-19 namun dirasa sikap pemerintah masih kurang tepat (Ristyawati, 2020). Hal ini dikarenakan menurut laporan WHO pertanggal 15 Juni 2020 dilaporkan kasus COVID-19 di Indonesia tercatat sebanyak 33.277 Kasus, menjadi negara kedua dalam kasus konfirmasi tertinggi negara terjangkit di ASEAN setelah Singapura sebanyak 40.604 Kasus (WHO, 2020). Dengan adanya virus Covid-19 ini telah meneyababkan adanya ketidak signifikan pendapatan nasional khususnya di Indonesia.

Dalam (Kusuma \& Maradona, 2020) Dikarenakan salah satu faktor penentu utama bagi kelangsungan proses pembangunan di suatu negara yakni pendapatan nasional suatu negara, agar proses pembangunan tersebut terus berjalan dan mengingat segala perencanaan pembangunan yang telah disusun akan menjadi sangat sulit terlaksana apabila tidak didukung oleh sumber daya keuangan yang memadai. Kondisi keuangan yang ideal akan segera dapat dicapai oleh suatu negara apabila negara tersebut memiliki sumber keuangan yang stabil dan kokoh (Enache, 2020), Mengingat pajak telah menjadi sumber utama bagi pendapatan/keuangan negara. Memungut pajak dengan efektif dan efisien merupakan salah satu fokus utama pemerintah manapun (Arbel et al., 2019), (Hammouri \& Abu-Shanab, 2017) dan (Mdanat et al., 2018). Kepatuhan dari wajib pajak merupakan sikap wajib pajak untuk bersedia melaksanakan kewajiban perpajakannya dan menggunakan hak perpajakannya dengan mengikuti ketentuan di dalam regulasi atau peraturan perundang-undangan perpajakan (Alm et al., 2017), (Hunt \& lyer, 2018), dan (Nkundabanyanga et al., 2017).

Pajak memiliki peranan yang sangat penting dalam memenuhi kebutuhan negara yang terus naik setiap tahunnya, bahkan pajak dapat dikatakan sebagai sumber pendapatan/keuangan utama negara. Seperti yang dijelaskan sebelumnya bahwa pajak merupakan kewajiban dari setiap warga negara untuk berkontribusi kepada negara dan sifat yang dimiliki oleh pajak merupakan memaksa kemudian untuk imbalan yang akan didapatkan oleh warga negara tidak akan dirasakan secara langsung hal ini dikarenakan pajak ini dipergunakan untuk keperluan negara yang ditujukan untuk kemakmuran seluruh masyarakat. Menurut Leroy Beaulieu, Pajak merupakan bantuan yang diberikan secara langsung maupun tidak langsung yang dipaksakan oleh kekuasaan publik dari penduduk atau dari barang, untuk menutup belanja pemerintah. Pajak sendiri memiliki banyak jenis yang salah satunya adalah Pajak Penghasilan Final (PPh Final).

Pajak Penghasilan Final (PPh Final) adalah potongan atas pendapatan tertentu yang telah dihasilkan oleh wajib pajak dimana alur maupun proses penghitungan pajaknya telah 
dianggap selesai saat dilakukannya pemotongan, pemungutan atau penyetoran sendiri yang dilakukan oleh wajib pajak tersebut. Pajak penghasilan final (PPh Final) mulai dikenal oleh banyak masyarakat sejak diberlakukannya pada pajak penghasilan final atas bunga deposito, sertifikat deposito, dan tabungan pada tahun 1989. Dalam perkembangannya, PPh sebagaimana diatur yang telah diatur dalam Undang-Undang Nomor 36 Tahun 2008 yakni Pasal 4 ayat (2), Pasal 15, Pasal 17 ayat (2d), Pasal 19, Pasal 21 dan Pasal 22, mengatur adanya 23 jenis penghasilan atau para wajib pajak yang diharuskan membayar PPh Final.

Wajib pajak pada umumnya diwajibkan untuk menyerahkan pungutan pajaknya secara langsung karena sifatnya pajak itu sendiri seketika. Pada dasarnya merupakan pajak yang memiliki skema tarif dan cara perhitungan yang berbeda dengan pajak penghasilan non-final. PPh Final ini langsung dikenakan dengan tarif dan dasar pengenaan pajak tertentu atas berbagai jenis penghasilan yang diperoleh Wajib Pajak (WP) selama satu tahun berjalan. Meringankan beban yang dimiliki oleh wajib pajak dalam menunaikan kewajiban perpajakan merupakan tujuan yang dimiliki oleh pemerintah ketika menetapkan aturan PPh Final ini.

Pengenaan PPh final memiliki tujuan agar penghasilan yang didapatkan atau diterima akan dipungut PPh dengan tarif tertentu dan dengan dasar pengenaan pajak tertentu pada saat penghasilan tersebut didapatkan. Pajak Penghasilan yang telah dipungut, baik yang dilakukan pemotongan oleh pihak lain maupun yang diserahkan sendiri oleh wajib pajak, dan bukanlah merupakan pembayaran yang dilakukan diawal atas PPH yang terhutang tetapi telah melakukan pelunasan PPh terutang atas penghasilan tersebut. Oleh karena itu, penghasilan yang telah dikenakan oleh PPh final tidak akan dikalkulasi lagi Pajak Penghasilannya. Di Surat Pemberitahuan Tahunan untuk dikenakan tarif global bersamaan dengan penghasilan lainnya. Begitu juga dengan PPh yang telah dipotong atau dibayarkan tersebut juga bukan merupakan kredit pajak di SPT Tahunan. Dengan ini kami melakukan studi kebijakan publik yang terkait dengan penjelasan diatas.

Lingkup dari studi kebijakan publik itu sendiri sangat luas, hal ini dikarenakan mencakup dari berbagai bidang dan sektor seperti bidang ekonomi, politik, sosial, budaya, hukum, dan sebagainya. Di samping itu melihat dari hirarki yang dimiliki oleh kebijakan publik, hirarki tersebut dapat bersifat nasional, regional maupun lokal seperti undang-undang, peraturan pemerintah, peraturan presiden, peraturan menteri, peraturan pemerintah daerah/provinsi, keputusan gubernur, peraturan daerah kabupaten/kota, dan keputusan bupati/walikota. kebijakan publik adalah: "Serangkaian keputusan kebijaksanaan yang diambil seorang atau sekelompok orang umumnya disebut pemerintah untuk mewujudkan tujuan-tujuan tertentu di dalam masyarakat" (Taufiqurokhman, 2014). Tentang kebijakan publik ini maka kami mengkaji tentang bagaimana implementasi dari kebijakan tersebut.

Implementasi merupakan suatu proses interaksi antara perangkat tujuan dan tindakan- 


\section{Journal Publicuho}

ISSN2621-1351 (online), ISSN 2685-0729 (print)

Volume 4 Number 2 (May-July), (2021)pp. 520-535

Accredited SINTA SK.NOMOR 28/E/KPT/2019

Open Access at:http://ojs.uho.ac.id/index.php/PUBLICUHO/index DOI: 10.35817/jpu.v4i2.18097

tindakan yang dilakukan untuk mencapai tujuan tersebut, dengan kata lain implementasi merupakan kemampuan atau keahlian untuk membentuk hubungan lebih lanjut sesuai dengan yang telah diharapkan dalam rangkaian sebab akibat menghubungkan tindakan dan tujuan. Oleh karena itu diperlukan adanya interaksi antar elemen yang bersangkutan dalam proses implementasi tersebut yang menjadi suatu hal yang vital dalam konsep implementasi. Secara sederhana dapat dikatakan bahwa implementasi merupakan suatu rangkaian kegiatan yang dilakukan untuk mengantarkan program atau kebijakan ke arah tujuan dan hasil yang diharapkan. Kecamatan Gedangan merupakan salah satu daerah yang di Kabupaten Sidoarjo dengan jumlah sekitar 13.900 UKM (Dinas Koperasi dan Usaha Mikro Kabupaten Sidoarjo, 2021; Dinas Koperasi dan UKM Provinsi Jawa Timur, 2020).

Tujuan dari penulisan kami adalah untuk mengetahui bagaimana implementasi Kebijakan Insentif Pajak terutama PPh Final yang ditujukan kepada UMKM dengan mengambil lokasi di Kecamatan Gedangan Kabupaten Sidoarjo bisa dilihat dari faktor-faktor yang dapat mempengaruhi implementasi antara lain :

\section{Komunikasi}

Dalam (Mariam, 2016) disebutkan Carl I Hovland (dalam Suhandang, 2009;14) menyatakan bahwa komunikasi adalah proses di mana seseorang/insan (komunikator menyampaikan rangsangan berupa lambang dalam bentuk kata-kata) untuk mengubah perilaku insan lainnya (hadirin). Insentif pajak yang sudah dikeluarkan oleh pemerintah melalui Kementerian Keuangan. Pada tahun 2020 dikutip dari (Wijoto, 2020) Kanwil DJP Jatim II terus mendorong penguatan dalam bidang ekonomi terutama pada sektor Usaha Mikro Kecil Menengah (UMKM) di Jawa Timur yang dikemas dengan acara sosialisasi Business Development Services (BDS) yang diikuti secara daring oleh 813 Pelaku UMKM di Jawa Timur. Acara tersebut dilaksanakan selama empat hari itu dilaksanakan dengan mengangkat tema "Peduli, Responsif, Adaptif Atasi Pandemi, Bangkitkan Ekonomi" acara sosialisasi ini yang sekaligus dalam rangka merayakan Hari Oeang Republik Indonesia (HORI) ke-74. Kepala Kanwil DJP Jawa Timur II Lusiani ketika memberikan sambutan telah berpesan kepada para peserta Business Development Services (BDS) yakni para pelaku Usaha Mikro Kecil dan Menengah untuk segera memanfaatkan salah satu fasilitas yang dikeluarkan oleh Menteri Keuangan melalui DJP dalam rangka mengimbangi pandemi Covid-19 yang sedang terjadi, yakni dengan pemberian insentif pajak kepada pelaku UMKM.

Sosialisasi insentif pajak yang sudah dilakukan oleh Kanwil DJP Jatim II baru saja dilakukan sekali pada November 2020 dan itu dilakukan secara daring sehingga terdapat beberapa dari para pelakU UMKM yang berada di Kecamatan Gedangan tidak mengetahui tentang adanya sosialisasi tersebut bahkan kebijakan insentif pajak PPh Final untuk UMKM itu sendiri. Dalam sosialiasi itu juga disebutkan bahwa lebih baik para pelaku 
UMKM memiliki NPWP (Nomor Pokok Wajib Pajak) yang maka apabila memiliki NPWP akan disebut sebagai wajib pajak, sehingga para pelaku UMKM bisa menikmati apa yang sudah diupayakan oleh pemerintah. Namun sayangnya ada beberapa UMKM di Kecamatan Gedangan yang belum memiliki NPWP, contohnya mereka yang berada di golongan usaha mikro, dengan alasan karena berfikir pendapatan yang diperoleh tidak besar bagi mereka tetapi diharuskan membayar Pajak PPh Final dengan beranggapan tentu akan merugikan bagi mereka yang pendapatannya tidak stabil. Dilihat dari segi komunikasi, dalam implementasi kebijakan dirasa masih kurang memadai. Hal ini dikarenakan kurangnya sosialisasi yang dilakukan Kanwil DJP Jatim II, yang mana sosialisasi tentang kebijakan insentif pajak untuk UMKM ini hanya dilakukan dalam satu kali. Dengan adanya sosialiasi tentu akan menambah pengetahuan bagi mereka yang membutuhkan, namun karena baru dilakukan satu kali saja menyebabkan terjadi kesenjangan dengan minimnya pengetahuan masyarakat tentang informasi mengenai insentif pajak UMKM. Masyarakat juga tidak banyak yang mengetahui bahwa informasi insentif pajak juga dapat dilihat melalui internet atau website resmi dari Direktorat Jenderal Pajak(DJP). Dari terjadinya sosialisasi yang dilakukan sekali dan kurangnya pengetahuan informasi melalui website, jadi masih banyak dari para pelaku UMKM tidak terlibat dalam pelaksanaan kebijakan tentang adanya Insentif Pajak PPh Final ini.

\section{Sumber Daya}

Sumber daya merupakan segala sesuatu yang bisa digunakan sebagai perlengkapan maupun peralatan dalam mendukung pengimplementasian setiap kebijakan terutama kebijakan yang dikeluarkan oleh pemerintah maka sumber daya dibutuhkan harus memiliki kualitas dan kuantitas yang memadai untuk mendukungnya. Dengan penelitian kami yang berjudul "Implementasi Kebijakan Insentif Pajak UMKM di Era Covid-19 di Kecamatan Gedangan Sidoarjo" sumber daya yang kami teliti adalah jumlah pelaku usaha baik pelaku usaha Mikro, Kecil, maupun Menegah. Berdasarkan hasil penelitian kami, jumlah seluruh Usaha Mikro di Gedangan Kabupaten Sidoarjo yang kami dapatkan dari Dinas Koperasi dan Usaha Mikro Kabupaten Sidoarjo, (2021) berjumlah 60 pelaku usaha Mikro kemudian untuk Usaha Kecil dan Menengah yang kami dapatkan dari Dinas Koperasi dan UKM Provinsi Jawa Timur, (2020) berjumlah 13.840 pelaku usaha Kecil dan Menengah. Kemudian, sumber daya manusia yang ditemukan dilapangan, dirasa adanya kekurangan dalam melakukan sosialisasi terhadap implementasi kebijakan tersebut, hal ini disebabkan pada saat sosialisasi daring dilakukan hanya diikuti sebanyak 813 pelaku usaha se Jawa Timur oleh karena itu tidak bisa dibandingkan dengan jumlah seluruh UMKM di Kecamatan Gedangan Kabupaten Sidoarjo, sehingga mengakibatkan para wajib pajak tidak seluruhnya mengetahui tentang adanya insentif pajak PPh Final khususnya untuk UMKM. Kerdasarkan hasil penelitian kami untuk sumber daya lainnya contohnya data primer yang dimiliki oleh 


\section{Journal Publicuho}

ISSN2621-1351 (online), ISSN 2685-0729 (print)

Volume 4 Number 2 (May-July), (2021)pp. 520-535

Accredited SINTA SK.NOMOR 28/E/KPT/2019

Open Access at:http://ojs.uho.ac.id/index.php/PUBLICUHO/index

DOI: 10.35817/jpu.v4i2.18097

pihak terkait, bisa dibilang merupakan data terbaru karena data yang kami minta dari Dinas Koperasi dan Usaha Mikro Kabupaten Sidoarjo dan Dinas Koperasi dan UKM Provinsi Jawa Timur merupakan hasil data dari Tahun 2020.

Dilihat dari segi Sumber Daya, implementasi kebijakan masih dirasa kurang dikarenakan adanya perbedaan perbandingan dari jumlah seluruh UMKM di Kecamatan Gedangan dengan jumlah pelaku UMKM yang mengikuti sosialisasi yang diadakan oleh Kanwil DJP Jatim II sehingga mengakibatkan Wajib Pajak ada yang tidak mengetahui dan tetap membayar pajak seperti biasa.

\section{Disposisi}

Disposisi bisa diartikan sebagai perintah dari atasan kepada bawahan. Berdasarkan penelitian kami di lapangan, terdapat sikap yang sudah baik karena sudah melakukan sosialiasi namun juga terdapat sikap kurang baik pelaksana kebijakan dalam memberi dukungan terhadap pelaksanaan kebijakan, hal ini dikarenakan ketika berada di lapangan diketahui bahwa sosialisasi terkait insentif pajak ini baru saja dilakukan satu kali dan masih belum ada agenda selanjutnya. Agar program yang diusung oleh pemerintah yang berlangsung hingga Juni 2021 dapat digunakan sepenuhnya, diharapkan DJP Kanwil Provinsi Jawa Timur II dapat melanjutkan kembali sosialisasi terkait insentif pajak sebelum masa berlakunya berakhir. Dari segi Disposisi, pelaksana kebijakan yang kurang memberikan kegiatan sosialisasi sehingga sosialisasi baru saja dilakukan satu kali yakni pada November 2020 dan masih belum saja memiliki agenda sosialisasi selanjutnya, dinilai memiliki sikap kurang baik karena ada kemungkinan masih banyak pelaku usaha yang tidak mengetahui terkait insentif pajak ini terutama pelaku usaha di Kecamatan Gedangan Kabupaten Sidoarjo.

\section{Struktur Birokrasi}

Dari susunan organisasi, maka dapat diketahui mengenai birokrasi, wewenang dan tanggung jawab dari sekelompok orang-orang yang terlibat dalam hubungan kerja sama yang ada pada kantor tersebut. Selain itu birokrasi juga akan memberikan gambaran mengenai sistem kerja dalam menunjang pelaksanaan kebijakan.

Menurut Dwiyanto (2006:56) yang dikutip dari La Ode Muhammad Elwan. (2019) bahwa pemberian pelayanan publik oleh aparatur pemerintah kepada masyarakat (publik) merupakan perwujudan dan fungsi aparatur negara sebagai pelayan masyarakat (abdi), disamping sebagai abdi negara. Dalam konteks ini masyarakatlah sebagai aktor utama (pelaku) pembangunan, sedangkan pemerintah berkewajiban untuk mengarahkan, membimbing serta menciptakan suasana yang menunjang kegiatan-kegiatan dari masyarakat tersebut. Pada kondisi ini aparatur negara dituntut untuk lebih mampu memperbaiki kinerjanya (pelayanan prima) dan diharapkan lebih mampu merumuskan 
konsep atau menciptakan iklim yang kondusif, sehingga sumber daya pembangunan dapat menjadi pendorong percepatan terwujudnya masyarakat yang mandiri dan sejahtera. Pelayanan yang telah menunjuk kepada aturan formal dianggap telah memenuhi sendisendi pelayanan yang baik dan aparat pelayanan dianggap telah konsisten dalam menerapkan aturan hukum pelayanan, (La Ode Muhammad Elwan, 2019)

Berdasarkan hasil penelitian diketahui bahwa Pph Final yang dibayarkan oleh UMKM yang apabila melalui offline dapat menuju ke KPP (Kantor Pelayanan Pajak) yang tersedia berdasarkan daerah setempat kemudian apabila melalui online dapat melalui laman www.pajak.go.id.

Setelah berada di masa Pandemi Covid-19 yang seluruh kegiatan dalam kehidupan dihentikan dan hanya ada pembatasan dalam berkegiatan, sehingga untuk melakukan pembayaran Pajak PPh Final untuk UMKM ini lebih diarahkan untuk membayar pajak di website pajak DJP. Dimasa Pandemi saat ini, perekonomian di seluruh dunia sedang terguncang tidak terkecuali Indonesia, sehingga Menteri Keuangan menurunkan Kebijakan Insentif Pajak bagi para Wajib Pajak salah satunya Insentif Pajak terutama Insentif Pajak yang diperuntukkan untuk UMKM, sehingga bagi mereka yang menginginkan insentif ini ada beberapa SOP (Standar Operasional Prosedural) dan syarat untuk mendapatkannya antara lain mengajukan permohonan kepada Direktur Jenderal Pajak melalui saluran tertentu pada laman www.pajak.go.id.

Dalam laman tersebut, Terdapat beberapa pilihan menu, klik menu login dan isi NPWP dan password untuk bisa login, setelah login, pilih menu layanan pada kotak menu atas, pilih KSWP (Konfirmasi Status Wajib Pajak). Pada kotak "Untuk Keperluan" pilih menu Surat Keterangan (PP 23). Apabila wajib pajak memenuhi kriteria maka diterbitkan Surat Keterangan. Ketika wajib pajak melakukan transaksi dengan pemotong atau pemungut, pajak yang muncul saat transaksi tidak dapat dilakukan pemotongan atau pemungutan PPh pada saat pembayaran atas PPh yang ditanggung pemerintah tersebut. Pemotong atau Pemungut wajib membuat Surat Setoran Pajak (SSP) atau cetakan kode billing yang diberi cap atau tulisan "PPH FINAL DITANGGUNG PEMERINTAH EKS PMK NOMOR 09 /PMK.03/2021". Ketika cap yang bertuliskan kalimat tersebut sudah dicetak, seperti yang dijelaskan diatas maka kewajiban yang dimiliki tidak perlu dibayarkan sampai dengan kebijakan ini berlaku yakni 30 Juni 2021. Dari segi Struktur Birokrasi ini, dikarenakan adanya pembagian tugas yang sudah jelas antara pelaku usaha yang ingin megurus via online maupun offline sehingga mampu membantu mereka kesusahan dalam memahami bagaimana insentif pajak yang sudah diberikan oleh Pemerintah. 


\section{Journal Publicuho}

ISSN2621-1351 (online), ISSN 2685-0729 (print)

Volume 4 Number 2 (May-July), (2021)pp. 520-535

Accredited SINTA SK.NOMOR 28/E/KPT/2019

Open Access at:http://ojs.uho.ac.id/index.php/PUBLICUHO/index

DOI: 10.35817/jpu.v4i2.18097

\section{KESIMPULAN}

Berdasarkan hasil dan pembahasan, maka dapat ditarik kesimpulan. Adapun kesimpulan dari penelitian ini antara lain :

1. Insentif Pajak ini sudah disosialisasikan oleh DJP Kanwil II Jawa Timur pada November 2020 yang lalu melalui daring dengan jumlah peserta 813 pelaku UMKM dari seluruh wilayah Jawa Timur yang berarti terjadi kesenjangan terhadap jumlah keseluruhan pelakU UMKM Kecamatan Gedangan yang berjumlah 13.900 UMKM selaku pelaksana sektor ekonomi maka hal ini menandakan bahwa tidak seluruh UMKM di Kecamatan Gedangan mengikuti sosialisasi terkait Insentif Pajak ini.

2. Dari segi komunikasi, implementasi kebijakan insentif pajak ini dirasa masih kurang. hal ini dikarenakan kurangnya sosialisasi dari DJP Kanwil II Jawa Timur yang mana hanya dilakukan satu kali dan masih ada berbagai pihak dari UMKM tidak mengetahui tentang adanya kebijakan Insentif Pajak ini.

3. Dari segi sumber daya, implementasi kebijakan masih dirasa kurang hal ini disebabkan ketika melakukan kegiatan sosialisasi terkait insentif pajak yang dilaksanakan secara daring dan hanya dilakukan satu kali sehingga mengakibatkan adanya Wajib Pajak ada yang mungkin tidak memahami dengan benar kebijakan ini, dan tidak mengetahui serta tetap membayar pajak seperti biasa.

4. Dari segi Disposisi, sikap yang diberikan oleh pelaksana kebijakan sudah cukup baik karena sudah mengadakan sosialiasi untuk membeitahu masyarakat terkait kebijakan yang sudah diturunkan ini namun terdapat sikap yang disesalkan yakni pelaksana kebijakan yakni Kanwil DJP Jawa Timur II yang hanya melakukan sosialisasi satu kali pada November 2020 sehingga mengakibatkan adanya kemungkinan pelaku usaha tidak mengetahui adanya insentif pajak ini dan tetap membayar pajak seperti biasa.

5. Dari segi Struktur Birokrasi, struktur yang dimiliki oleh pelaku kebijakan dirasa sudah bagus hal ini dikarenakan sudah adanya pembagian tugas dalam pengurusan Pajak PPh Final yang sudah ditetapkan dan apabila melalui online dan mengajukan syarat terkait dapat ditujukan kepada website DJP itu sendiri sehingga untuk poin ini, implementasi kebijakan kami anggap sudah memenuhi kriteria struktur birokrasi yang baik.

Berdasarkan hasil, pembahasan, dan kesimpulan penelitian kami, maka yang dapat kami disarankan adalah diharapkannya untuk DJP Kanwil Jawa Timur II agar segera melakukan sosialisasi kembali sebelum masa berlaku Insentif Pajak yang diberikan ini berakhir, karena rasanya akan tidak adil bagi mereka yang tetap melakukan pembayaran pajak di masa Pandemi Covid-19 ini dan diharapkan KPP setempat juga membantu DJP Kanwil Jawa Timur II untuk melakukan agenda sosialisasi selanjutnya. 


\section{REFERENSI}

Aminullah, A., \& Setyasih, D. M. (2021). Implementasi Retribusi Daerah Pelayanan Kesehatan Di Uptd Kesehatan Puskesmas Puspo. Journal Publicuho, 4(1), 59-68. https://doi.org/10.35817/jpu.v4i1.16232

Anggara, S. (2014). Kebijakan Publik. Bandung: Pustaka Setia.

Aningtiyas, D. R. S. (2020). Geliat UMKM di Kala Pandemi. Retrieved March 3, 2021, from djp website: https://www.pajak.go.id/id/artikel/geliat-umkm-di-kala-pandemi

Dinas Koperasi dan Usaha Mikro Kabupaten Sidoarjo. (2021). Buku Profil Dinas Koperasi dan Usaha Mikro Kabupaten Sidoarjo.

Dinas Koperasi dan UKM Provinsi Jawa Timur (2020). Data Koperasi \& UKM. Retrieved May 1, 2021, from Diskopukm website: https://data.diskopukm.jatimprov.go.id/bank_data/

Dewantari, K. M. (2021). Insentif Pajak Diperpanjang, Manfaatkan Segera! Retrieved March 3 , 2021, from djp website: https://www.pajak.go.id/id/artikel/insentif-pajak-diperpanjangmanfaatkan-segera

Hel/Waw. (2020). Kembangkan Ribuan UMKM Sidoarjo, BHS Siapkan Empat Sentra Kawasan Industri Mikro. Retrieved March 3, 2021, from RepublikJatim website: https://republikjatim.com/baca/kembangkan-ribuan-umkm-sidoarjo-bhs-siapkanempat-sentra-kawasan-industri-mikro

Kadim, R. (2015). Implementasi Kebijakan Program Listrik Pintar Di Kecamatan Palu Timur. E Jurnal Katalogis, 3(9), 87-96.

Keban, Y. (2004). Enam Dimensi Strategis Administrasi Publik, Konsep, Teori, dan Isu. Yogyakarta: Gava Media.

Kusuma, I. gusti P. A., \& Maradona, A. F. (2020). Peran Intelijen Perpajakan dalam Meningkatkan Penerimaan Pajak. E-Jurnal Akuntansi, 30 (8), 1957-1968. https://doi.org/10.24843/EJA.2020.v30.i08.p05

La Ode Muhammad Elwan. (2019). PROBLEM BIROKRASI DALAM MENINGKATAN PELAYANAN PUBLIK PADA SEKRETARIAT DAERAH KABUPATEN MUNA. In Copyright@2019 Journal PUBLICUHO Faculty of Social and Political Sciences Halu Oleo University (Vol. 2). Retrieved from http://ojs.uho.ac.id/index.php/PUBLICUHO

Maharatih, N. W. (2019). Studi Kritis Pengenaan Pajak Penghasilan Final Bagi Usaha Mikro Kecil Menengah. Jurnal Magister Hukum Udayana (Udayana Master Law Journal), 8(1), 105115. https://doi.org/10.24843/jmhu.2019.v08.i01.p08

Mariam. (2016). Implementasi Kebijakan Jaminan Kesehatan Nasional (JKN) Pada Dinas Kesehatan Kabupaten Sigi. E Jurnal Katalogis, 4(3), 37-46.

Moleong, L. J. (2005). Metodologi Penelitian Kualitatif. Bandung: Remaja Rosdakarya.

Muhyiddin, M., \& Wardhana, D. (2020). Covid-19 Outbreak and Development Planning in Indonesia. Jurnal Perencanaan Pembangunan: The Indonesian Journal of Development Planning, 4(1), iv-vi. https://doi.org/10.36574/jpp.v4i1.108

Mulyadi, D. (2019). Implementasi Kebijakan Pemberian Bantuan Keuangan Kepada Pemerintah Desa di Kabupaten Bandung. Jurnal IImu Administrasi: Media Pengembangan Ilmu Dan Praktek Administrasi, 16(1), 66-80. https://doi.org/10.31113/jia.v16il.208

Padyanoor, A. (2020). Kebijakan Pajak Indonesia Menanggapi Krisis COVID-19: Manfaat bagi Wajib Pajak. E-Jurnal Akuntansi, 30(9), 2216-2230. https://doi.org/10.24843/eja.2020.v30.i09.p04

Pratiwi, M. I. (2020). Dampak Covid-19 terhadap perlambatan ekonomi sektor umkm. Jurnal 


\section{Journal Publicuho}

ISSN2621-1351 (online), ISSN 2685-0729 (print)

Volume 4 Number 2 (May-July), (2021)pp. 520-535

Accredited SINTA SK.NOMOR 28/E/KPT/2019

Open Access at:http://ojs.uho.ac.id/index.php/PUBLICUHO/index DOI: 10.35817/jpu.v4i2.18097

Ners Universitas Pahlawan, 4(2), 30-39.

Resmi, S. (2019). Perpajakan Teori \& Kasus. Yogyakarta: Salemba Empat.

Ristyawati, A. (2020). Efektifitas Kebijakan Pembatasan Sosial Berskala Besar Dalam Masa Pandemi Corona Virus 2019 oleh Pemerintah Sesuai Amanat UUD NRI Tahun 1945. Administrative Law and Governance Journal, 3(2), 240-249. https://doi.org/10.14710/alj.v3i2.240-249

Rozzaq, M., \& Widiyarta, A. (2021). IMPLEMENTASI PROGRAM BANTUAN BAGI PELAKU USAHA MIKRO. Journal Publicuho, 4 (2), 315-325. https://doi.org/10.35817/jpu.v4i2.17858

Saraswaty, A. N. (2018). Kebijakan Publik Dan Ritel Modern: Studi Kasus Pelaksanaan Kebijakan Plastik Berbayar. E-Jurnal Ekonomi Dan Bisnis Universitas Udayana, 7(1), 113142. https://doi.org/10.24843/eeb.2018.v07.i01.p05

Supriadin, R., Alam, S., \& Elwan, L. O. M. (2020). IMPLEMENTASI PERATURAN WALIKOTA KENDARI NOMOR 13 TAHUN 2008 TENTANG PENATAAN PEDAGANG KAKI LIMA DI KOTA KENDARI. Journal Publicuho. https://doi.org/10.35817/jpu.v3i1.11506

Undang-Undang Nomor 28 Tahun 2007.

Wahab, S. A. (2001). Analisis Kebijakan dari Formulasi ke Implementasi Kebijaksanaan Negara. Jakarta: Bumi Aksara.

Wijoto, R. (2020). Perkuat Ekonomi UMKM dan Sosialisasi Insentif Pajak, Kanwil DJP Jatim II Gelar BDS Selama 4 Hari. Retrieved April 8, 2021, from beritajatim.com website: https://beritajatim.com/ekbis/perkuat-ekomoni-umkm-dan-sosialisasi-insentif-pajakkanwil-djp-jatim-ii-gelar-bds-selama-4-hari/

Yuliana, Y. (2020). Corona virus diseases (Covid-19): Sebuah tinjauan literatur. Wellness And Healthy Magazine, 2(1), 187-192. https://doi.org/10.30604/well.95212020 